\title{
Romanian Literature as World Literature. Edited by Mircea Martin, Christian Moraru, and Andrei Terian.
}

New York: Bloomsbury, 2018. 376 pp.

\section{Zoltán Z. Varga}

Institute for Literary Studies, Research Center for Humanities, Budapest / Department of French Studies, Faculty of Humanities and Social Sciences, University of Pécs, Hungary; z.varga.zoltan@gmail.com

In the past few decades, theories of world literature have been among the most interesting subfields of research in comparative literature. The idea of a unified but unequally structured network of national literatures, modeled by mutual interdependency and power relationships, not only provided possibilities for developing new, transnational literary histories but also offered fresh perspectives on literary histories of a specific country or geopolitical region. Enterprises like the four volumes of the History of the Literary Cultures of East-Central Europe (2004-10) edited by John Neubauer and Marcel Cornis-Pope, or French Global (2011) edited by Christie McDonald and Susan R. Suleiman, prefer deliberately to approach a national or regional literary production as parts of world literature, showing their specificities in a transnational context. The series "Literatures as World Literature" launched in 2014 by Bloomsbury belongs to this comparative approach of literary history since local literary phenomena are treated in the light of global poetical issues. The series, which is edited by Thomas Oliver Beebee, has already proved hugely popular amid the international comparatist readership, as the total number of seventeen volumes published in such a short period proves. The general concept of the series itself seems to take up the challenge of writing a history of world literature in the age of globalization, in the context of the ever-growing scale and the more diversified nature of the new world literature that is no longer limited to a selective Western canon of atemporal and (presumably) universal masterpieces.

The series's volumes form at least three subclasses: there are books dedicated to particular authors (three by now, Roberto Bolaño, Samuel Beckett and Elana Ferrante); volumes which explore literary genres, discourses or supranational literary movements (Crime fiction, Surrealism, Philosophy as World Literature), and lastly, volumes devoted to the study of linguistic or geographical entities' (or their combinations') literatures (mainly national literatures, but not always, as was 
borne out by volumes of Afropolitan, Francophone and Multilingual literature). Contingent as it may seem, these (expandable) thematical nodes are likely to disclose the "worldly" dimensions of particular literary works, genres, movements, and traditions "over deep time and across long space", beyond ethno-territorial and national paradigms. The seemingly aleatory succession of the volumes is not intended to give a systematic and comprehensive representation of the new world literature (which would hardly be possible, because of the liberty given to the editors of each volume), and above all it does not attempt to totalize a field which cannot be totalized because of its historicity and its dependence on the theoretical framework in which it is defined.

Despite the heterogeneous nature of the emerging publications, we should admit that the "Literatures as World Literature" series offers a notable opportunity to the literatures of the so-called "minor languages" (which represent the majority of the volumes) to put themselves on the prestigious map of world literature, to use today's cartographic cliché. The introduction of literature in minor languages (Bulgarian, Turkish, Brazilian, Danish, Dutch and Flemish, and Romanian) or some minor aspects of literature in major languages (German, American English) differs considerably from traditional literary history in the sense that they do not intend to present a coherent historical narrative to an indigenous readership mostly familiar with the cultural and historical context of a particular national literature; rather they aim at a global professional, English speaking readership. The implied reader's alterity is one of the (hermeneutical) reasons why the "native's" point of view on their own cultural production remains in the background (the volumes are edited and written by experts of the local culture), while a more general perspective of world literature with a stronger theoretical framework is promoted, therefore a reader less familiar with a particular national context can also have access to a local variation on an already known comparative or historical problem. The methodological shift does not only provide hermeneutical advantages to find easier contacts with a less-known culture's literature, but also shows-through comparative archeology-that a seemingly closed and self-sufficient cultural product with its own forms, topics, and language is formed in permanent (but not necessarily simultaneous) confrontation with the cultural alterity.

Romanian Literature as World Literature with its "inevitably selective look at the geo-historically constituted Romanian literary network and at the forms, venues, and connecting mechanisms in and through which Romanian texts come along and function" (p. xiv) leans obviously on truly transnational topics: there are chapters on the role Romantic poetry played in nineteenth-century nation-building, on Romanian artists in the international avant-garde network, on extraterritorial and minority "microliteratures" within or beyond the nation-state borders, on émigré and exiled literature, on political, ideological and poetic issues of Social Realist literature, etc. 
These topics are like open gates through which international readers enter more easily into Romanian literature's "worldedness" and understand "its intersectional position in the network-world." (p. 3) The opening chapter of the volume, entitled The Worlds of Romanian Literature and the Geopolitics of Reading, reads like a real critical-theoretical manifesto by two of the editors. In their introduction to the volume, Christian Moraru and Andrei Terian develop an anti-exceptionalist thesis insofar as they "decline to trace Romanian literature's world itineraries by hopping from one isolated literary 'peak' to another" (p. xv), in other words, to present the richness of the Romanian literature to an (ignorant) international public by selecting its most famous (eventually internationally acclaimed) authors and masterpieces. Instead of a naïve canon-forming and emancipatory intention, the editors consider Romanian literature as a "particular nodal point" and they try to pursue "textual and intertextual trajectories running through its ethnolinguistic and geoadministrative nodes" (p. 7).

Needless to say, their approach challenges "the ethno-territorial and nationalist paradigm" (p. 13) of the nineteen-century style's domestic literary historiography based on "a deployment of stable and cut-and-dried essences, monistic cultural morphologies, one-of-a-kind ethnoracial 'character', unwavering teleologies, and other fictions of this sort" (p. 4). However, such concepts as nation and nationstate remain important for Moraru and Terian when describing the transnational connections of Romanian literature. For example, they not only reject the haunting concept of the Herderian "national soul" (which conceives national identity in terms of essence, difference, particularity, etc.), but propose a contextual analysis of its reoccurrence and its recycling in different historical circumstances (as is illustrated by their reading of Georges Călinescu's 1941 History of Romanian Literature from Its Origins to the Present, and of the Critical History of Romanian Literature: Five Centuries of Literature written by Nicolae Manolescu in 2008). The deconstruction of the notion of nation as a closed and self-sufficient entity has a double epistemological and ideological (political) importance according to the editors of Romanian literature as World literature: epistemological, because "the nation-state as an analysis unit $[\ldots]$ and state backed epistemology have arguably become overbearing in their territorialism and increasingly inadequate as knowledge tools," (p. 12) especially to explain the logic of twenty-first century artistic and cultural production; and political, because a rigid concept of the nation as a unified and homogenous agent in the worldwide power game for symbolic prestige tends to reproduce the hierarchical relationship of nation-state players in terms of influence, belatedness, cultural imitation, central and peripheral positions.

Romanian Literature as World Literature disapproves of forms of cultural (and quite openly political) insularism and it supposes a more intimate relationship between the national and world literature, a "copresence of the national and the worldly, their mutual and multilayered imbrication." For that reason, the editors 
propose an intersectional approach to map out "national identity, its much-debated uniqueness, and literature as a reliable vehicle for this distinctiveness." (p. 3) The case studies and the thorough analysis try to convince the reader of how deeply the worldly, with its multifaceted forms, is embedded into the seemingly self-sufficient national culture; the authors of the volumes reveal how "cultural poiesis denaturalizes the 'national' in 'national culture' and thereby helps cultural understanding," they "disclose culturally "classified" information about the recycled material's worldly provenance or, conversely, about the worldly affiliations of presumably discrete traditions and autonomous identities." (p. 13)

Following the introductory chapter's strong theoretical position, the volume is divided into three proportionally sized parts. The first part, entitled The Making and Remaking of a World Literature: Revisiting Romanian Literary and Cultural History, proposes a metacritical approach to the history of Romanian literature, and contains the few papers which do not focus only on modern literature (that is to say on the literature of the twentieth century). In the opening chapter, Andrei Terian confronts the Romanticist myth of the national poet as the incarnation of a pure and culturally homogenous national essence. He follows the nineteenth century romanticist poet Mihai Eminescu's career to show how the Romanian national poet acquired this prestigious position through his integration-at two levels-into a worldwide literary system, into the system of freshly born world literature. Firstly, Terian argues that the notion of the national poet is a transnational construction occurring during the consolidation of national identity, and the "very status of national poet inevitably implies, then, a multiple if often elusive inscription into a global or, at least, transnational literary circuit." (p. 36) In other words, to be recognized as a fully-fledged nation among other nations, a nation must have its own national poet, but paradoxically the criteria and models of this prestigious institution are defined abroad, therefore even the usage of the notion implies a transnational dimension. But Terian finds another, this time, (inter)textual argument to prove the transnational inspirations of Eminescu's work. By investigating Eminescu's failure to write an epic verse narrative on a national, historical subject-the genre par excellence of the nationalist-romanticist movements-he reveals how the tension between Western forms (perceived as an imitable authority without organic cultural connection) and the thematic of the heroic national past prevented the poet from composing a "Romanian Homeric epic poem, a Romanian Shakespearean dramatic cycle, or a Romanian Faustian poem." (p. 42) According to Terian, Eminescu overcame his cultural inferiority complex and his "anxiety of influence" by discovering via the work of Schopenhauer the Vedic tradition which he considered "as part of 'Romanian' folklore, and so he felt free to handle the Vedas as he would domestic material; that is, immune to any anxiety-inducing pressure to prove himself by equaling and possibly outshining the model in the originality department." (p. 48) Terian's case study reveals not only 
the transnational dimensions of a theme which seems to belong most eminently to a strict national tradition, but also that the old comparatist interpretative tool of "influence" can work in a much broader temporal and spatial context (over deep time and long space) without being an arbitrary reading operation.

The other papers in the first part offer a metacritical perspective on the pre-modern history of the Romanian literature, too. In his Aux portes de l'Orient, and Through: Nicolae Milescu, Dimitrie Cantemir, and the "Oriental" Legacy of Early Romanian Literature Bogdan Creţu tackles the problem of integrating medieval and early modern, mostly non-fictional written works (travelogues, compilations, commentaries, etc.) into national literary history. Their integration into the history of the national literature seems problematic because the writings in question were produced before the constitution of the literature as a (national) institution and before the birth of the modern notion of the nation(-state). He analyses the strategies by which the representative Romanian literary histories placed the essentially transnational and multilinguistic literary productions "into the service of state, national, and nationalist agendas," (p. 55) by discovering forerunners of nationalist thought in premodern cosmopolitan and multilingual intellectuals. Much in line with Crețu's paper, Alex Goldiş focuses on the role that some important Romanian nineteenth-century literary historiographies played in the construction of the national identity. According to Goldiş, in that respect Romania is no exception among Central and Eastern European countries trying to overcome their "cultural complex" compared with the "Westeither expressed by spatial ("marginality") or temporal terms ("belatedness") - "by converting the inferiority complex into a superiority complex." (p. 100) He argues that, quite surprisingly, cultural protectionist strategies do not necessarily exclude comparative operations but he also warns that the comparative approach of literary historians like Călinescu "does not shed light on the transnational flows, exchanges, and influences," it only points out "structural symmetries [with Western literature] popping up in national literature deus ex machina-like." (p. 102) Goldiş also criticizes the cultural isomorphism employed by Eugen Eugen Lovinescu in his literary history, where he identifies "local counterparts to every major movement of modern French culture," (p. 102) and by the same move, reduces their interactions to "a one-way account of colonial appropriation." (p. 106)

The second part of the volume, entitled Literature in the Plural, contains papers dealing with works of literature produced in Romania which could be qualified as "minority" literature. In the opening, theoretical chapter of the second part Mircea A. Diaconu proposes the term microliterature to refer to "a literary culture that builds up its identity cross-statally and in conjunction with another or several other literatures within and without the host country." (p. 137) Today's Romania offers multiple opportunities for studying microliteratures, as beside the considerable Hungarian and the once also important German communities' literatures, 
there are significant extraterritorial Romanian communities with their own literatures (especially Moldavian-Romanian literature, but also ethnic Romanian writers from Serbia). Diaconu describes the microliterature writers' situation in terms of "unhomeliness" as they are usually ignored by both the intra- and the extraterritorial majority, and therefore they make a special effort to find their proper public, and to be recognized by either local, or extraterritorial majoritarian literary communities. He surveys some of the strategies that extraterritorial Romanian writers develop, and by analyzing the oeuvre of Adam Pusłojić, a Romanian writer from Serbia, he points out how difficult it is to deal with writers with double belonging: "it cannot be easily determined if indeed his Serbian-language work conveys a Romanian 'affect structure' and therefore makes him a Romanian poet of Serbian expression, or if he is a Serbian poet who happens to have an important work in Romanian also" (p.154). Although he switched to the language of the majoritarian community, the Romanian (therefore also the French) literary tradition remained deeply ingrained in his work. The triangular structural determination (and the different degrees of political repression exerted on former Soviet-bloc countries) can be discovered in the work of Ion Druţă, a Moldavian Romanian author also writing in Russian who advocated the universalism of literature, as a tool to overcome to his own particular-that is to say: national-conditions. But this typical ideological strategy under Communist rule had ambiguous effects, because despite its seemingly friendly intention to surmount divisive nationalism and reinforce international identity constructions, it was often perceived as a means of repression (by Russian imperialism), and, as a counter-effect, it contributed to the rise of nationalist movements as a form of political and ideological opposition during Soviet times.

If the belonging to two (or, as we have seen, three) literary systems is easily perceptible in the case of extraterritorial Romanian authors, the situation is slightly different in the case of Transylvanian Hungarian Literature, and also German literature from Romania, especially if one seeks the place of the former in Romania's literature. Imre József Balázs in his Trees, Waves, Whirlpools: Nation, Region, and the Reterritorialization of Romania's Hungarian Literature "read[s] Hungarian literature produced in Romania as an evolving, geoculturally roving, multiply affiliated discourse system" and "propose[s] a critical dive into this literature's 'whirlpool' to uncover the inner workings of literary mechanisms writers activate to take apart and complicate selfhood, belonging, community, territory, and other similar notions." (p. 158). Balázs argues that "nationally and regionally minded" attempts with their organic metaphors ("soil" and "root")—on the part of both Hungarian and Romanian literary historiography-have only limited possibilities to grasp "the trans-territorial and cross-cultural aspect" of Hungarian literature produced in Romania. What he proposes instead is a "reading-centered approach" which could open up "the 'regional' object to the world along both the synchronic and diachronic 
axes" (p. 162). After surveying the institutional frameworks and attempts to integrate "minority" literatures into Romanian literature during the interwar period, then in state-socialist times, he concludes that intraterritorial microliteratures, especially the Hungarian one, and Romanian majoritarian literature followed separatealbeit sometimes parallel-tracks until the recent occurrence of postmodernist fiction. His thorough readings demonstrate how "situations, names, people, and places from their country's contemporary history, art, and literature," or in other words, the locality "frays and decomposes but only to disseminate across a wide expanse of other locales" (p. 167) in novels like Ádám Bodor’s 1992 Sinistra körzet (The Sinistra Zone), Zsolt Láng’s 1997-2012 trilogy Bestiárium Transylvaniae (Transylvanian Bestiary), and István Szilágyi’s 2001 Hollóidő (Time of Ravens). According to Balázs these novels' narrative strategies with their "disembodied narrative voice", and their "anachronistic and ahistorical or dehistoricizing chrono-topological references" reduce the chances of an essentialist-regionalist appropriation-which would shrink, once again, Hungarian literature produced in Romania to its own presumed essences-, moreover, Bodor, Láng and Szilágyi's narrative poetic allow "a genuinely intersectional and thereby less hegemonic commerce between Romanian literature and Hungarian literature from Romania." (p. 171)

Other papers in the second part discuss identity-poetical questions related to the particular development of literary and social modernity in Romania during the interwar period. Ovidiu Morar, in his Cosmopolites, Deracinated, Etranjuifs: Romanian Jews in the International Avant-Garde traces back how the particular socio-historical circumstances of pre-Great War Romania influenced the deracinating and deterritorializing poetics of internationally acclaimed Romanian avant-garde artists of Jewish decent during their artistic debut. The case of Tristan Tzara, whose pen name is a telling multilingual pun ("triste en son pays" - triste (sad in French) en (in in French) țară (country in Romanian) is relatively well known, and Morar shows us how the Romanian avant-garde's uprooting/re-enrooting poetics, with its "free verse, ostentatiously prosaic poetry, and, conversely, poetic prose, alongside the collage-like, arbitrary agglutinations of heterogeneous information, and the jarringly illogical analogies," (p. 182) had already occurred in Tzara's pre-Dada poetry written in Romanian. Beside Tzara's case, Morar analyzes a radical poetic of uprootedness, introducing the stammering, phonetic poetry of Gerashim Luca (discovered for a wider Western public by Giles Deleuze), whose works "according to the same 'negative' logic of deracination not to 'enrich' poetic language in an ornamental sense but to take it in the opposite direction of the 'deliberately impoverishment' Deleuze and Guattari deem paramount to minor literature practices," (p. 187) and leads, by the vocalization of the writing, finally to the "eloquent disappearance" of the poet(ical subjectivity) à la Mallarmé (which the poet realized tragically and literally by drowning himself to the Seine in Paris, just as his compatriot Paul Celan had done). 
The third and final major part of the volume, entitled Over Deep Time, across Long Space, contains papers which focus on comparatist problems connected to geopolitical transformations after World War II and their consequences for Romania's relations with the worldwide literary system. The Communist period and the Sovietization of the cultural arena seem particularly interesting not only for the Romanian scholars of social and cultural history but also for an international readership. Yet, it is not surprising that five of the six chapters of the last part can be connected to that issue, dealing with the questions of exile and emigration, ideological control, and Soviet-type colonization. Mihai Iovănel's Rebranding Games and Global Relevance after the Second World War-Mircea Eliade, E. M. Cioran, Eugene Ionesco traces how the three iconic Romanian intellectuals successfully resumed and rebuilt their careers in France having already achieved national celebrity, and how they managed to depoliticize their work and to hide their shady political past. Iovănel seeks to explain their success story by leaning on Pascale Casanova's world literature concept, in which she describes the literary game-players' actions and strategies according to their position in the unequally structured global literary space. He explains the Romanian triad's success in a central cultural system with their ability to "become competitive by forging a non-mimetic relationship with adoptive culture," (p. 223) to deploy an innovative strategy in it. The question is how they could develop those abilities or, in Boudieuan terms, the "habitus" and "disposition" required for successful professional behavior. By outlining their socio-cultural formation and position in Romania, Iovănel emphasises that all of them had already built in their native country a partly international intellectual network; they had more or less reliable foreign language skills. But the key to their successful rebranding in France, according to Iovănel, can be ascribed to their even wider international reception, notably their North American and English recognition (Eliade won a professorship in Chicago, Cioran was noted by the influential New York intellectual, Susan Sonntag, Martin Esslin's Theatre of the Absurd contributed considerably to Ionesco's fame), and their lasting popularity could be explained also by their infiltration into the popular culture (Eliade had also an impact on the hippy movements' esoteric pseudo-philosophy, Cioran's eloquently expressed blasé nihilism appeared even in the first season of the HBO television series, True Detective, in which the memorable character of detective Rustin Cohle's speech is inspired by the Romanian writer's works.)

Mircea Martin, the third editor of the volume, explores in his chapter the impact that Socialist realism had on Romania's literary system. No doubt, Martin's paper aims at disillusioning those scholars who take pleasure in the historical and theoretical debates on Socialist Realism without ever experiencing the reality of Socialism. The way he outlines cultural politics may sound very familiar to the whole ex-Soviet bloc's readership, because Martin focuses on the general aspects of Socialist 
Realism as an ideology (with its institutions) and as a poetics, and he suggests their interconnectedness as well. Martin introduces the socialist realist cultural politics and poetics without its inner-often considerable-temporal transformations, as an essentially immutable ideological construction. Local differences between the Central and East European socialist countries are not explored as Martin prefers to depict Socialist Realism as "an artificial cultural-ideological construct whose uniform and simultaneous implementation across this transcontinental expanse gave birth [...] to a geoliterary ecumene." (p. 236) This ecumene, the common ideological ground for an international community, was realized—argues Martin—by a forced denationalization of cultural history which implied also the rewriting of the national literary histories reduced to a selective "progressive" tradition. In the most original parts of his chapter, he reveals the inner contradictions of socialist realist literary representation. He argues that socialist realist literature was not realist at all, because instead of representing the rather sad and poor reality under communist regimes, the difficulties of everyday life under dictatorship and political repression, literary fictions rather represented an idealized image of socialist life, society and its population in a constantly deferred future. Unfortunately, the paper's intention to give a general image of socialist realist representation is developed at the expense of the description of the specificities of Romanian Socialist Realism which, in the form it took under Ceaușescu's socialist nationalism in the seventies and the eighties, constituted an exception among Eastern-bloc countries.

In that respect, Michaela Ursa's closing chapter on translation policies satisfies the reader's expectations. Ursa sketches a historical survey on the changing function of translation in the history of Romanian literature. As several papers of the volume have already claimed, the formation and the institutionalization of national literature in Romania (and in other East- and Central European countries) played an important role in the nation-building project. So did translation, and "the development of a translational corpus was part and parcel of nation building," claims Ursa. (p. 311) However, during the nineteenth century, Romanian literati were divided with regard to the benefits of a translational culture. According to pro-translation critics "translations, adaptations, borrowings, and the like ultimately gave Romanian literature a chance not only to make itself but also to make itself coeval with other literatures inside the cultural Eurosystem and even to make itself distinct from them." (p. 312) On the other side, translation- and influence-skeptics feared that the imported foreign works and the practice of cultural imitation might corrupt the intrinsic national forms and themes and their originality, and might be dangerous to the development of the national identity. The line of division separates not only poetical but also political positions. It runs between two concepts of national identity: between an organically developed, essentialist nationalist program on the one hand, and a relationist, dialogic one on the other, encouraging deeper Europeanization. Michaela 
Ursa shows that in the nineteenth century's literary translation, mostly aimed at scaling the peaks of the centrally positioned "major language's" literature, "aspiring to meet some day their standards of "universality," (pp. 310-11) and the vertical interest in "minor" literature positioned at the same level as the Romanian occurred later in the history of Romanian literature, and that the interest itself was often reduced to exotism. The import of the already approved cultural products from centrally situated cultures was not only a sign of snobbery but also an attempt at cultural modernization, "'catching up' with Western Europe;" (p. 313) moreover, at creating "Romanian-language reincarnations of 'universal' cultural models, [...] elements of an exclusive world canon. For more than 200 years, these items have been presented to the national audience as pinnacles of literary craftsmanship." (p. 310)

For the Romanian modernity movements that were more focused on the (usages of) poetic language itself, translation meant on one hand importing more innovative cultural/literary technologies, but also producing "renditions that make the alien domestic, accessible to local audiences, and the familiar national language 'foreign' and by the same token ready to carry a national literature." (p. 313)

During the decades of Communist rule in Romania, translation policy conformed to the Soviet bloc's ideological expectations, and translations from friendly communist allies were supported. However, Ceaușescu's socialist nationalism loosened its ties with the Soviet Union, and Romania, in the middle of a small cultural revolution, turned more toward the West, especially toward France, which possessed the highest cultural capital among Romance languages at that time. Interestingly enough, during the apogee of political neo-Stalinization, a large number of "translations from foreign theorists from the Russian Formalists to the French poststructuralists and from Northrop Frye and René Wellek to Paul Ricoeur, Jean Starobinski, and Hans Robert Jauss" were published in Romania. The works of the most important Western critics inspired the writers of fiction and poets of the 80's generation, because "Cărtărescu and his friends were well read not only in the great canon of American poetry and fiction but also in criticism and theory, and this background shows in their works, in which the theoretical, philosophical, intertextual, metalinguistic, and self-reflective elements characteristically abound." (p. 315) Early acquaintance with those influential theoretical schools probably also made for a smoother transition of Romanian literary criticism into a Western-type academic paradigm.

1989 was a landmark in the history of translation in Romania as well. It marked not only the end of the ideologically controlled translation policy but also the end of a centrally guided translation program in the service of nation-building. "In Romania," concludes Ursa, "the previously monolithic, nation-state oriented, often nationalist translation program has yielded to a range of uncoordinated-'microprograms' in which the translational, alongside other domains, discourses, and practices of national culture, characteristically does the bidding of the transnational." (p. 309) 
Romanian Literature as World Literature is an ambitious enterprise to synthesize some important contemporary pieces of research on world literature while introducing the Romanian literature's "worldliness" to an international readership. Instead of reducing the comparative investigations to a search for causal, mechanical and hierarchical types of influence exerted by world literature on Romanian literature, or investigating the latter's sporadic occurrences on the "great stage" of literature in the major languages, the volume offers a more complex (and more interesting) way to reveal the multiple types of relationships they keep. The intersectional methodology considers national literature as an open geopoetical and geopolitical space which is at once wider and smaller than the one-language-centered, nation-state oriented, territorially closed frame of observation that characterises most national literary historiography. In this intersectional space, the geopolitical reading discloses multilateral comparative correlations such as the local transformations of supranational poetical or ideological movements and their feedback into the world system, the geopolitical contexts behind poetic forms and narrative constructions, etc.

The geopolitical reading proposed by the Romanian Literature as World Literature has certainly a political dimension, as it overtly criticizes the essentialist concept of the national literature which leads to cultural insularism, chauvinism, and hard-line nationalism. Yet, I believe, it does this with the intention not of destroying but of deconstructing myths of national uniqueness and their product in national literary history, since a comparative reading rather explains their genesis and meaning in the context of an intercultural and transnational dialog. To that extent, the volume is a committed piece of scholarship, which is aware of its performative power, aware of its responsibility to represent the connection of the national and the worldly to avoid the dangers of cultural insularism on the one hand, and of self-colonization on the other.

https://orcid.org/0000-0001-6377-6058

(c) 2021 The Author(s). This is an open-access article distributed under the terms of the Creative Commons Attribution-NonCommercial 4.0 International License. 